\title{
Increasing evidence of the rise of cancer in workers exposed to vinylchloride
}

\author{
V B SMULEVICH, ${ }^{1}$ I V FEDOTOVA, ${ }^{2}$ V S FILATOVA ${ }^{2}$ \\ From the All-Union Cancer Research Centre, ${ }^{1}$ AMS USSR, Moscow, and Institute of Occupational Medicine, ${ }^{2}$ \\ Gorky, USSR
}

ABSTRACT The results of a cancer mortality study among workers employed in the production of vinylchloride and polyvinylchloride between 1939 and 1977 suggest a significant increase in deaths from malignancies of the lymphatic and haemopoietic tissues. Mortality for tumours of the digestive organs, respiratory system, bone and connective tissues, brain, and skin are also greater than in the general population. There were no registered cases of liver angiosarcoma in the study cohort during the follow up period. The risk of cancer was highest among the workers exposed to concentrations of $\mathrm{VC}$ of $300 \mathrm{mg} / \mathrm{m}^{3}$ and more who had worked at the plant for 15 to 19 years. The relatively high number of leukaemias and lymphomas in the study group and the absence of liver angiosarcomas probably reflects specific carcinogenic action of different doses of vinylchloride.

The carcinogenicity of vinylchloride (VC) has been studied only recently although this compound was synthesised almost 150 years ago ${ }^{1}$ and its industrial production in many countries started in the late 1930s.

The first clinical and hygiene study of the occupational setting and health of workers in plants producing VC and polyvinylchloride (PVC) was undertaken in the USSR in the early 1950s. This study showed heavy air pollution with VC in the shops of the plant, reaching levels of $100-800 \mathrm{mg} / \mathrm{m}^{3} .^{2}$ This exposure resulted in a high frequency of occupational toxic angioneuroses in the workers ${ }^{3}$ and led to the legislative limitation in the USSR (1957) of the VC level in the working zone to a maximum permissible concentration (MPC) of $30 \mathrm{mg} / \mathrm{m}^{3}$.

VC and PVC induced diseases in the workers producing these agents were described later by several foreign authors. ${ }^{4-6}$ Officially established MPCs of $\mathrm{VC}$ in the working zone in several countries before 1974 were as follows: United States $-770 \mathrm{mg} / \mathrm{m}^{3}$; Italy, France, Finland, and Yugoslavia-1300; East Germany-500; West Germany-260; and Rumania-100. ${ }^{7}$

In 1970 Viola published the results of his animal experiments that were aimed at reproducing the acroosteolysis observed in PVC workers. The animals developed tumours of the lung and skin and led the author to conclude that VC was carcinogenic. ${ }^{8}$ Many

Accepted 20 October 1986 other workers have confirmed that $\mathrm{VC}$ is carcinogenic to animals..$^{9-14}$ In 1974 the first reports on cases of liver angiosarcoma among workers occupationally exposed to VC appeared. The frequency of this disease in the exposed groups was 300 to 600 times higher than in the general population. ${ }^{1516}$

The study presented here was aimed at evaluating the prevalence of malignant disease among workers employed between 1939 and 1977 in several Soviet enterprises producing VC and PVC.

\section{Materials and methods}

The base of the study was one of the oldest Soviet chemical plants where VC and PVC have been produced for various periods and under different technological patterns.

The data on the specified workers were obtained from the registers of the administrative department and from attendance journals and lists of particular shops. For every member of the study cohort the following data were collected: specified occupation, duration of employment in a VC exposed job, data and cause of death, and results of any postmortem study. The documents analysed were the death certificate, medical histories of disease, and necropsy protocols of those who had died from cancer.

The cohort included all employees who had worked in a VC exposed job for at least one month as well as those who had changed their place of employment, were retired, left through ill health, or were dead. 
Thus the study cohort consisted of 3232 workers (2195 men, 1037 women).

The death rates in the cohort were determined by considering both the number of observed subjects and the period of observation. ${ }^{17}$ The numbers of personyears of observation for the entire cohort was 43216 (27059 for men, 16157 for women).

The expected numbers of cases of cancer for the cohort were based on the mean death rates in the city where the plant is located for the years 1959, 1969, and 1975 in the age group 15-74. The extent of risk was evaluated by means of standardised mortality ratios (SMRs). The significance of the difference between the rates on the $p$ level $\leqslant 0.05$ was determined by the confidence limits of the variation of cancer frequency. ${ }^{18}$

The results of the hygiene study of the occupational environment in VC production for the period 1953-66 were treated by methods of variational statistics with identification of average VC concentrations for particular workplaces. ${ }^{19}$

The extent of VC influence on the workers resulting from the average VC doses that they had been exposed to while working was estimated within the following gradation:

high level-mean concentrations of $\mathrm{VC}$ $>300 \mathrm{mg} / \mathrm{m}^{3}$;

moderate level $-\mathrm{VC}$ concentrations $30-300 \mathrm{mg} / \mathrm{m}^{3}$; low level-concentrations $<30 \mathrm{mg} / \mathrm{m}^{3}$.

For the quantitative estimation of the "share" of VC and PVC in the total process of cancer development in the workers of this industry the technique of factorial dispersion analysis ${ }^{20}$ was used.

\section{Results}

Between 1939 and 1977288 deaths were registered in the cohort, including 63 from cancer. Histological confirmation of the diagnosis of cancer was available for $60 \%$ of the cases.

As shown by the SMRs, the workers in VC-PVC plants have an increased cancer mortality by comparison with the general population of the city (table 1). This was particularly noticeable for lung tumours, pancreas, bones and connective tissue, skin, and brain. The observed mortality from leukaemias and lymphomas is significantly higher than expected. No cases of angiosarcoma or other liver tumour were noted.

For the male workers exposed to VC, the total cancer mortality was somewhat lower than in the male population of the city. The numbers of cases of pancreatic cancer, lung cancer, tumours of the bones and genitalia, and leukaemias, however, were higher than expected but not significantly so.

The cancer mortality for the female workers was greater than expected due to malignancies of the stomach, rectum, skin, brain, and lymphatic and haematopoietic tissues. The excess for leukaemias and lymphomas was statistically significant.

As was clear from the analysis of working conditions at the plant there were three categories of workers based on the intensity of exposure to VC-PVC. The first group (highest exposure) consists of the workers of the major occupations (apparatus operators, fitters) employed in producing VC by dehydrochlorination of dichlorethane in the

Table 1 Observed number of deaths from cancer (Obs) and SMRs of cancer in the cohort of VC and PVC workers

\begin{tabular}{|c|c|c|c|c|c|c|c|}
\hline \multirow[b]{2}{*}{ Sites } & \multirow[b]{2}{*}{$I C D 8,1965$} & \multicolumn{2}{|l|}{ Men } & \multicolumn{2}{|c|}{ Women } & \multicolumn{2}{|c|}{ Both sexes } \\
\hline & & $O b s$ & $S M R$ & Obs & $S M R$ & Obs & $S M R$ \\
\hline All malignancies & $140-209$ & 44 & $98 \cdot 2$ & 19 & $153 \cdot 8$ & 63 & $106 \cdot 6$ \\
\hline Oral cavity and pharynx & $141-149$ & 0 & - & 0 & - & 0 & - \\
\hline Digestive organs: & $150-159$ & 17 & $74 \cdot 8$ & 8 & $121 \cdot 2$ & 25 & $85 \cdot 0$ \\
\hline Oesophagus & 150 & 0 & - & 0 & - & 0 & - \\
\hline Stomach & 151 & 14 & $83 \cdot 3$ & 7 & 142.9 & 21 & $84 \cdot 7$ \\
\hline Rectum & 154 & 0 & $\overline{1}$ & 1 & $125 \cdot 0$ & 1 & $50 \cdot 0$ \\
\hline Pancreas & 157 & 3 & $172 \cdot 2$ & 0 & - & 3 & $142 \cdot 9$ \\
\hline Liver & & 0 & - & 0 & - & 0 & - \\
\hline Respiratory organs: & $160-163$ & 18 & $141 \cdot 7$ & 0 & - & 18 & $134 \cdot 3$ \\
\hline Larynx & 161 & 1 & $100 \cdot 0$ & 0 & - & 1 & $83 \cdot 3$ \\
\hline Trachea, bronchus, lung & 162 & 17 & $145 \cdot 3$ & 0 & - & 17 & $139 \cdot 3$ \\
\hline Bones and connective tissue & $170-171$ & 1 & $166 \cdot 7$ & 0 & - & 1 & $142 \cdot 9$ \\
\hline Skin & $172-173$ & 0 & $\cdots$ & 1 & $1000 \cdot 0$ & 1 & $200 \cdot 0$ \\
\hline Breast & 174 & 0 & - & 0 & -- & 0 & - \\
\hline Reproductive organs & $180-187$ & 1 & $125 \cdot 0$ & 2 & $71 \cdot 4$ & 3 & $83 \cdot 3$ \\
\hline Urinary organs & $188-189$ & i & $38 \cdot 5$ & 0 & - & 1 & $34 \cdot 5$ \\
\hline Brain and nervous system & $191-192$ & 2 & $90 \cdot 9$ & 2 & $500 \cdot 0$ & 4 & 153.8 \\
\hline Leukaemia, aleukaemia & $204-207$ & 3 & $428 \cdot 6$ & 2 & $666 \cdot 7$ & 5 & $500 \cdot 0^{*}$ \\
\hline $\begin{array}{l}\text { Other malignancies of lymphatic and } \\
\text { haematopoietic tissue }\end{array}$ & $\begin{array}{l}200-203,208 \\
209\end{array}$ & 1 & $100 \cdot 0$ & 4 & $2000 \cdot 0^{*}$ & 5 & $416 \cdot 7^{*}$ \\
\hline
\end{tabular}

*Significant at $\mathrm{p}<0.05$. 
Table 2 Observed deaths from cancer (Obs) and SMRs in subgroups of workers with various exposures to VC

\begin{tabular}{|c|c|c|c|c|c|c|c|}
\hline \multirow{2}{*}{$\begin{array}{l}\text { Level } \\
\text { of exposure to VC }\end{array}$} & \multirow[b]{2}{*}{ Sites } & \multicolumn{2}{|l|}{ Men } & \multicolumn{2}{|c|}{ Women } & \multicolumn{2}{|c|}{ Both sexes } \\
\hline & & $O b s$ & $S M R$ & Obs & $S M R$ & $O b s$ & $S M R$ \\
\hline High & $\begin{array}{l}\text { All sites: } \\
\text { Stomach } \\
\text { Lung } \\
\text { Lymphomas, leukaemias }\end{array}$ & $\begin{array}{r}28 \\
8 \\
13 \\
8\end{array}$ & $\begin{array}{r}101 \cdot 4 \\
79 \cdot 2 \\
171 \cdot 1 \\
300 \cdot 0\end{array}$ & $\begin{array}{r}12 \\
5 \\
0 \\
4\end{array}$ & $\begin{array}{l}444 \cdot 4^{*} \\
384 \cdot 6^{*} \\
4000 \cdot 0^{*}\end{array}$ & $\begin{array}{r}40 \\
13 \\
13 \\
7\end{array}$ & $\begin{array}{l}132 \cdot 0 \\
114 \cdot 0 \\
168 \cdot 8 \\
636 \cdot 4^{*}\end{array}$ \\
\hline Moderate & $\begin{array}{l}\text { All sites: } \\
\text { Stomach } \\
\text { Lung } \\
\text { Lymphomas, leukaemias }\end{array}$ & $\begin{array}{r}15 \\
5 \\
4 \\
1\end{array}$ & $\begin{array}{l}107 \cdot 1 \\
122 \cdot 0 \\
129 \cdot 0 \\
166 \cdot 7\end{array}$ & $\begin{array}{l}5 \\
2 \\
0 \\
1\end{array}$ & $\begin{array}{l}113 \cdot 6 \\
133 \cdot 3 \\
-142 \cdot 9\end{array}$ & $\begin{array}{r}20 \\
7 \\
4 \\
2\end{array}$ & $\begin{array}{l}108 \cdot 7 \\
128 \cdot 8 \\
125 \cdot 0 \\
153 \cdot 8\end{array}$ \\
\hline Low & $\begin{array}{l}\text { All sites: } \\
\text { Stomach } \\
\text { Lung } \\
\text { Lymphomas, leukaemias }\end{array}$ & $\begin{array}{l}1 \\
1 \\
0 \\
0\end{array}$ & $\begin{array}{l}31 \cdot 3 \\
83 \cdot 3 \\
-\end{array}$ & $\begin{array}{l}2 \\
0 \\
0 \\
1\end{array}$ & $\begin{array}{l}28 \cdot 2 \\
-\quad 333 \cdot 3\end{array}$ & $\begin{array}{l}3 \\
1 \\
0 \\
1\end{array}$ & $\begin{array}{l}29 \cdot 1^{*} \\
27 \cdot 0 \\
\frac{200 \cdot 0}{20}\end{array}$ \\
\hline
\end{tabular}

*Significant at $\mathrm{p}<0.05$.

medium of methyl alcohol and in producing PVC in the suspension who worked in these shops from the beginning of their employment up to 1959 (when certain improvements in working conditions were realised).

The second group (moderate exposure) is represented by the workers in the new shops producing PVC with modern technology and those who were employed before 1971 in drying departments and apparatus operators in the polymerisation departments where PVC was produced with imported technology.

The third group (low exposure) is composed of employees of the new shops, the drying workers employed between 1971 and 1977 and laboratory assistants and other workers having minor contact with VC.
The first and second occupational groups had a increased SMR for all cancers (table 2). More men in these groups died than in the general male population from cancer of the stomach and lung and from leukaemias. It is of interest that only in the high and moderate exposure groups of male workers were cases of lung cancer noted. This supposes some effect of smoking, an essential factor in the development of lung cancer ${ }^{21-23}$ that might enhance the carcinogenic influence of VC.

Among the female workers exposed to the highest doses of VC, the SMRs are high and significant for malignancies of the stomach, and for leukaemias and lymphomas.

The workers in the lowest exposure group also had the lowest SMRs.

Table 3 Observed deaths from cancer (Obs) and SMRs in various subgroups of workers by duration of employment and exposure to $\mathrm{VC}$

\begin{tabular}{|c|c|c|c|c|c|c|c|}
\hline \multirow[b]{2}{*}{ VC level } & \multirow[b]{2}{*}{ Duration of employment (years) } & \multicolumn{2}{|l|}{ Men } & \multicolumn{2}{|c|}{ Women } & \multicolumn{2}{|c|}{ Both sexes } \\
\hline & & Obs & $S M R$ & Obs & $S M R$ & Obs & $S M R$ \\
\hline High & $\begin{array}{c}0-4 \\
5-9 \\
10-14 \\
15-19 \\
\geqslant 20\end{array}$ & $\begin{array}{r}18 \\
5 \\
2 \\
2 \\
1\end{array}$ & $\begin{array}{r}113 \cdot 2 \\
104.2 \\
90.9 \\
181.8 \\
66.7\end{array}$ & $\begin{array}{l}1 \\
5 \\
1 \\
4 \\
1\end{array}$ & $\begin{array}{c}68 \cdot 5 \\
714 \cdot 3^{*} \\
333 \cdot 3^{*} \\
1333 \cdot 3^{*} \\
500 \cdot 0\end{array}$ & $\begin{array}{r}19 \\
10 \\
3 \\
6 \\
2\end{array}$ & $\begin{array}{l}108 \cdot 1 \\
181.8 \\
120.0 \\
428.6^{*} \\
117.6\end{array}$ \\
\hline Moderate & $\begin{array}{l}0-4 \\
5-9 \\
10-14 \\
15-19 \\
\geqslant 20\end{array}$ & $\begin{array}{r}11 \\
3 \\
0 \\
1 \\
0\end{array}$ & $\begin{array}{l}111 \cdot 1 \\
130 \cdot 4 \\
\overline{166} \cdot 7 \\
-\end{array}$ & $\begin{array}{l}1 \\
1 \\
2 \\
0 \\
1\end{array}$ & $\begin{array}{r}47.6 \\
76.9 \\
105 \cdot 3 \\
-\quad 142.9\end{array}$ & $\begin{array}{r}12 \\
4 \\
2 \\
1 \\
1\end{array}$ & $\begin{array}{r}100 \cdot 0 \\
111.1 \\
58 \cdot 8 \\
71.4 \\
90.9\end{array}$ \\
\hline Low & $\begin{array}{c}0-4 \\
5-9 \\
10-14 \\
15-19 \\
\geqslant 20\end{array}$ & $\begin{array}{l}1 \\
0 \\
0 \\
0 \\
0\end{array}$ & $\begin{array}{l}47 \cdot 6 \\
- \\
- \\
-\end{array}$ & $\begin{array}{l}0 \\
0 \\
0 \\
2 \\
0\end{array}$ & $\begin{array}{l}\bar{z} \\
\overline{2} \\
-\end{array}$ & $\begin{array}{l}1 \\
0 \\
0 \\
2 \\
0\end{array}$ & $\begin{array}{l}25 \cdot 6 \\
\overline{250 \cdot 0} \\
-\end{array}$ \\
\hline
\end{tabular}

*Significant at $p<0.05$. 
Thus there is a clear relation between cancer mortality and the level of VC exposure in the study cohort: the workers subjected to doses higher than $30 \mathrm{mg} / \mathrm{m}^{3}$ have a higher risk of cancer than those with minimal contact with this compound.

Table 3 presents the distribution of deaths from cancer in the groups with different periods of employment. The highest SMR is in the group having worked at the plant for 15-19 years.

The treatment of the results by factorial dispersion technique for estimating the share of influence of VC (in dependence of level and duration of its action) on the risk of cancer have confirmed its significant role $(5.8 \%, p<0.001)$ in the development of tumours among the exposed workers.

\section{Discussion}

Our study has shown an increased cancer mortality in the workers employed in the production of $\mathrm{VC}$ and PVC, compared with the general population. An increased frequency in malignancies of the digestive organs, respiratory tract, brain, and lymphatic and haematopoietic tissues observed in this study is in accord with the results of similar studies of workers in VC-PVC plants in the United Kingdom, W Germany, France, United States, and other countries. ${ }^{24-29}$

In our study no angiosarcomas were noted; these tumours are considered by some authors to be a specific occupational disease of VC workers. ${ }^{23} 30$ The reason for this lack of angiosarcomas may be due to the measures for limiting airborne levels at work which were introduced earlier than in other countries and to effective protection (by relevant individual devices) of workers in high exposure jobs. On the other hand, it may reflect a certain specificity of action on the organism of various VC concentrations; higher doses lead to the development of liver angiosarcomas whereas moderate ones may affect other organs. This idea is to some extent confirmed by animal experiments ${ }^{14}$ with different doses of VC $(3690,266$, 25 , and $14 \mathrm{mg} / \mathrm{m}^{3}$ ) where the lowering of administered VC doses was accompanied by a change in the ratio of liver malignancies, lymphomas and leukaemias towards the production of the latter.

The finding of significant increases in SMRs for lymphomas and leukaemias, especially among female workers who usually have lower occupational exposures to VC than male workers is noteworthy. This probably reflects a higher susceptibility of the women to the carcinogenic action of $\mathrm{VC}$ but this hypothesis needs further study.

The relation between the carcinogenic action of VC and the level of exposure agrees with experimental evidence on this subject. ${ }^{12}$ This gives hope that current measures for limiting VC exposure at work (low- ering of the MAC in the USSR to $0.1 \mathrm{mg} / \mathrm{m}^{3}$, promotion of the hermitic sealing of the equipment used, and development of the non-stop technologies of VC production) will effectively serve to prevent the carcinogenic effects of VC on workers.

\section{References}

1 Regnault V. Composition of a chlorinated hydrocarbon (oil from oil-forming gases). Justus Liebig's Annales Chemistry 1835;14:22-38.

2 Filatova VS, Gronsberg ES, Sanitary and hygienic labour conditions in production of polychlorvinyl tar and measures of their improvement. Gigijena i sanitarija 1957;N1:38-42.*

3 Smirnova NA. Clinical features of the professional toxic angioneuroses. In: Materialy po voprosam gigieny truda i cliniky professionaligch boleznej Gorky 1956:44 52.*

4 Sucui J, Driman J, Valaskai M. Contributii la studiue imbalnaviritor produse de chlorure de vinil. Med Intern 1963; 15:967-78.

5 Wilson RH, McCormick WE, Tatum CF, et al. Occupational acroosteolysis. JAMA 1967;201:577-81.

6 Juhe $H$, Lange CE. Sclerodermiartige Hautferändeeungem Rejnaud-Syndrom und Acroosteolison bei PVC-Herstellenden Industre. Dtsch Med Wochnschr 1973;97:1922-3.

7 Nikitin VS, Rjabets VA. MPC of the noxious substances in the workshops air in the USSR and abroad. In: Nauchnye Raboty Instituta ohrany truda Vsesojuznogo Centralnogo Soveta Professionaligch Sojuzor Moscow' 1973;84:22-9.*

8 Viola PL. Carcinogenic effect of vinylchloride. In: Tenth International Cancer Congress, Houston, 1970. Vol 29. Houston: Medical Art Publishing Co, 1970.

9 Maltoni C, Lefemine G. Vinyl chloride carcinogenesis current results and perspective. Med Lav 1974;65:11-12.

10 Caputo A, Viola PL, Bigotti A. Oncogenic response of rat skin, lungs and bones to vinyl chloride. Cancer Res 1971;31:516-22.

11 Lee CC, Blandari GC, Winston JM, et al. Inhalation toxicity of vinyl chloride and vinylidene chloride. Environ Health Perspect 1977:21:25-35.

12 Maltoni C, Lefemine G, Ciliberty A, et al. Carcinogenicity bioassays of VCM: a model of risk assessment on an experimental basis. Environ Health Perspect 1981:41:3-29.

13 Stovbur NN, Kurliandsky BA, Turusov VS. Towards the rationale of the permissible vinylchloride contents in the working zone air. In: Tezisy dokladov 6 Vsesojuzhol conferencii. Leningrad: 1979:288.*

14 Kurliandsky BA, Stovbur NN, Turusov VS. Towards the question of hygienic reglamentation of vinyl chloride. Gigiena i Sanitarija 1981:3:74-86.*

15 Creech JL, Johnson ML. Angiosarcoma of the liver in the manufacture of PVC. J Occup Med 1976;16:150-1.

16 International Agency for Research on Cancer: Working group on vinyl chloride. Lyon: IARC, 1974. (Int tech report N74/005.)

17 MacMahon B. Pugh T, Ipsen J. The use of epidemiologic methods in the studies of noninfectious diseases. Moscow Meditzina, 1966. (Translated into Russian.)

18 Dvoirin VV. Analytical methods of the study in cancer epidemiology research. In: Chaklin AV, ed. Cancer epidemiology in CMEA countries. Moscow: Meditzina, 1979.

19 Merkov AM, Poliakov LE. Sanitary statistics. Leningrad: Meditzina. 1974.*

20 Plohinsky NA. Biometry. Moscow: Moscow State University, 1970.*

21 Serebrov Al. Tobacco smoking and lung cancer. Sov Med 1978;7:109-12.*

22 Chaklin AV, Gritzute LA. Modern concepts about aetiology and pathogenesis of lung cancer. Vopr Onkol 1982;2:3-9.*

*In Russian. 
23 Doll R, Peto R. The causes of cancer. Oxford, New York: Oxford University Press, 1981.

24 Buffler PA, Wood S, Eifler C, et al. Mortality experience of the workers in a VCM production plant. $J$ Occup Med 1979;21:195-203.

25 Byren D, Engholm G, England A, et al. Mortality and cancer morbidity in a group of Swedish VCM and PVC production workers. Environ Health Perspect 1976;17:167-70.

26 Fox AJ, Collier PF. Low mortality rates in industrial cohort studies due to selection for work and survival in the industry. $\mathrm{Br} J$ Prev Soc Med 1976;30:225-30.
27 Monson RR, Peters JN, Johnson MN. Proportional mortality among VC workers. Lancet 1974;ii:397-8.

28 Ott MG, Langner RR, Holder BB. Vinyl chloride exposure in a controlled industrial environment. A long-term mortality ex perience in 594 employees. Arch Environ Health 1975;30:333-9.

29 Waxweiller RJ, Stringer W, Jones J, et al. Neoplastic risk among workers exposed to vinyl chloride. Ann NY Acad Sci 1976; 271:40-8.

30 International Agency for Research on Cancer. Monographs on the evaluation of the carcinogenic risk of chemicals to humans. Vol 19. Lyon: IARC, 1979:377-438.

\section{Vancouver style}

All manuscripts submitted to the $B r J$ Ind Med should conform to the uniform requirements for manuscripts submitted to biomedical journals (known as the Vancouver style)

The $B r J$ Ind Med, together with many other international biomedical journals, has agreed to accept articles prepared in accordance with the Vancouver style. The style (described in full in Br Med J, 24 February 1979, p 532) is intended to standardise requirements for authors.

References should be numbered consecutively in the order in which they are first mentioned in the text by Arabic numerals above the line on each occasion the reference is cited (Manson' confirmed other reports ${ }^{2-5} \ldots$. In future references to papers submitted to the $B r J$ Ind Med should include: the names of all authors if there are six or less or, if there are more, the first three followed by et al; the title of journal articles or book chapters; the titles of journals abbreviated according to the style of Index Medicus; and the first and final page numbers of the article or chapter.

Examples of common forms of references are:

I International Steering Committee of Medical Editors. Uniform requirements for manuscripts submitted to biomedical journals. Br Med J 1979;1:532-5.

2 Soter NA, Wasserman SI, Austen KF. Cold urticaria: release into the circulation of histamine and eosino-phil chemotactic factor of anaphylaxis during cold challenge. $N$ Engl $J$ Med 1976;294:687-90.

3 Weinstein L. Swartz MN. Pathogenic properties of invading micro-organisms. In: Sodeman WA Jr, Sodeman WA, eds. Pathologic physiology: mechanisms of disease. Philadelphia: W B Saunders, 1974:457-72. 